\title{
Development of the Pedagogical Content Knowledge Scale for Pre-Service Teachers: The Validity and Reliability Study
}

\author{
Assistant Prof. Dr. Zeki Aksu \\ Faculty of Education, Artvin Coruh University, Artvin \\ zekiaksu25@hotmail.com \\ Assoc. Prof. Dr. Mustafa Metin \\ Faculty of Education, Bozok University, Yozgat \\ mustafametinae@hotmail.com \\ Assoc. Prof. Dr. Alper Cihan Konyalığlu \\ Faculty of Education, Atatürk University, Erzurum \\ ackonyali@yahoo.com
}

Doi:10.5901/mjss.2014.v5n20p1365

\section{Abstract}

The aim of this study is to develop a scale to determinate pre-service teachers' pedagogical content knowledge. The research was carried out with the 768 pre-service teachers in different universities in Turkey. The study consists of five parts including a literature review, an item pool, experts' opinions, administration of scale and computing the reliability and validity. While constituting the pool of items, an interview was carried out with 15 pre-service teachers regarding pedagogical content knowledge and 20 teachers were asked to write an essay related to this topic. The draft scale obtained was administered to 768 pre-service teachers and the result of factor analysis, the number of items was reduced to 38. Besides, the CronbachAlpha internal integrity coefficient of the final version of the scale was found to be 0.967 . After computing the reliability of PCKS, the scale is ready to be used.

Keywords: Content knowledge, pedagogical knowledge, pedagogical content knowledge, ,scale development.

\section{Introduction}

Teacher proficiencies are described as necessary knowledge skill and attitudes for instructors to fulfil the teacher profession effectively and efficiently (MNE, 2008). The qualifications which teachers are required to obtain have been the issues of many researches for a long time. According to studies related to teachers' proficiencies it was deduced that teachers were expected to do more than simply transmitting knowledge to students quickly. Nonetheless "teacher knowledge" is described in different ways and the necessary characteristics have been denoted differently.

Shulman (1986) investigated the necessary content knowledge that teachers are required having under three components. These were content knowledge, pedagogical content knowledge and curriculum knowledge in 1986. Afterwards, Shulman (1987) stated that seven categories given below constitute the teacher profession's base.

1. Content Knowledge

2. General pedagogical knowledge including classroom management and classroom organisation

3. Curriculum knowledge including materials and programmes.

4. Knowledge of learners and their characteristics.

5. Knowledge of educational contexts

6. Knowledge of educational ends, purposes, values and their philosophical and historical grounds

7. Pedagogical content knowledge

Shulman is the first person who proved pedagogical the content knowledge as necessary characteristics for teachers to possess. Shulman believes that simply understanding a subject well is not enough to teach this subject.

The field of education as a large body of the research conducted within 20 years has focused on teachers' and preservice teachers' pedagogical content knowledge (An, Kulm \& Wu, 2004; Carpenter, Fennema, Peterson \& Carey, 1988). 
In these studies, the component of pedagogical content knowledge defined by Shulman (1987) and Grossman (1990) was investigated.

Combination of content knowledge and pedagogical knowledge constitutes pedagogical content knowledge.

Figure 1. Pedagogical Content Knowledge

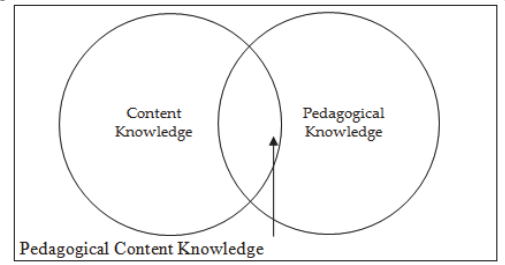

\subsection{Content Knowledge}

This contains the knowledge of the subject which is taught or learnt (Mishra and Koehler, 2006). Teachers and preservice teachers must understand all the knowledge in their subjects. Content knowledge is a type knowledge which covers concepts related to the teaching topic, operations, evidence and proof and problem solving skills (Shulman, 1986). The idea that having exact and good knowledge on the teaching subject is very important with regard to teachers and necessary comprehensive knowledge is necessary to quality education is generally accepted (Begle, 1979; akt: Akkoc, Ozmantar \& Bingolbali, 2008; Kahan, Cooper \& Bethea, 2004; Ball, 1988; akt: Akkoc, Ozmantar \& Bingolbali, 2008). The fact that teacher do not have enough content knowledge may impede students learning the subject well. Therefore, students may learn incorrect knowledge and have misconceptions (National Research Council, 2000; Pfund \& Durt, 2000).

\subsection{Pedagogical Knowledge}

This is concerned with the teaching process and methods also include knowledge about classroom management, developing a lesson plan, evaluation in order that students are able to learn. Pedagogical knowledge can be seen as necessary knowledge for teachers to have to know in depth the application of teaching and learning methods. This knowledge contains knowledge about understanding how students learn, planning an instruction, assessing students and general classroom management skills. Pedagogical knowledge includes knowledge about methods and strategies used in the classroom. It is also accepted as essential formation of the knowledge to understand learners' qualities and evaluate their learning (Koehler and Mishra, 2009).

\subsection{Pedagogical Content Knowledge}

This applies the content knowledge concerned with the teaching process. Shulman (1986a, 1986b, 1987) emphasised that content knowledge is not enough for effective teaching solely and pedagogical content knowledge is necessary. Shulman described pedagogical content knowledge as knowledge going beyond subject matter instruction. According to Shulman, pedagogical content knowledge includes:

'The most regularly taught topics in one's subject area, the most useful forms of representation of those ideas, the most powerful analogies, illustrations, examples, explanations, and demonstrations-in a word, the ways of representing and formulating the subject that make it comprehensible to others... pedagogical content knowledge also includes an understanding of what makes the learning of specific topics easy or difficult: the conceptions and preconceptions that students of different ages and backgrounds bring with them to the learning of those most frequently taught topics and lessons.'(s.9)

Pedagogical content knowledge contains either content knowledge or general pedagogical content knowledge. Shulman (1986) defined pedagogical content knowledge as the representations and teaching form which are the most useful representations, the strongest simulations, paint, samples and illustrations.

\subsection{Importance of the Study}

Pedagogical Content Knowledge (PCK) has risen as an important factor for teachers to conduct effective instruction, because powerful PCK is correlated with students' success in a positive way (Carpenter, Feeneme, Peterson, Chiang \& 
Loef, 1989; Rovegno, 1992). Teachers with strong PCK focus on their students' thinking/understanding make appropriate explanations for the cognitive level of students, present content which consider students' need with samples, metaphors and many teaching strategies more accurately (Gudmundsdottir, 1990; Wilson \& Winwberg, 1989). Teachers possessing better pedagogical content knowledge understand that setting problems and explanations for students are as important as asking questions (Griffin, Doods \& Rovegno, 1996). Use of simple reminding questions requiring knowledge can be accepted as the indicator of the low level of pedagogical content knowledge (Carlsen, 1987; Cochran, 1997). Pedagogical Content Knowledge (PCK) ensures opportunities for teachers with knowledge about teaching activities, the programme standard, teaching strategy and schools, students and society transfer to students (Griffin, Doods \& Rovegno, 1996). PCK provides knowledge about how subject titles, problems and their results are organised, presented and adapted into students' skills and interest (Clermont, Krajcik \& Borko, 1993). When PCK is investigated in depth, it is an important precursor for teachers to improve themselves from an apprentice executive to a professional executive (Clermont, Krajcik \& Borko, 1994).

There are numerous studies related to pedagogical content knowledge in international literature (Chick, H. L., 2009; Cochran, DeRuiter \& King, 1993; Dershimer \& Kent, 2003; Fernandez-Balboa \& Stiehl, 1995; Gess-Newsome, 1999; Grossman, P.L., 1990; Magnusson, Krajcik \& Borko, 1999; Marks, 1990; Smith \& Neale, 1989; Thoren, Kellner, Gullberg, Attorps, 2008; Zembylas, 2007). However, in Turkey there are only a few studies regarding this topic. The number of studies on teacher competency development has been increasing gradually in the field of mathematics (Akkoc, Yesildere \& Ozmantar, (2007); Akkoc, Ozmantar \& Bingolbali, 2008; Boz, 2004; Türnüklü, 2005; Yesildere, 2008) and especially science teaching (Canbazoglu, 2008; Gödek, 2002; Usak, 2005). Several survey studies have been conducted about technological pedagogical content knowledge in this field. Schmidt et al. (2009) developed scales on technological pedagogical knowledge. Timur \& Tasar (2011) conducted a study on adaptation of the scale of technological pedagogical content knowledge self-confidence, which was developed by Graham, Burgoyne, Cantrell, Smith \& Harris (2009). Sahin (2011) carried out a survey research on technological pedagogical content knowledge. A survey research is thought to make a remarkable contribution to the literature so as to research teachers' and pre-service teachers' PCK competency.

Although there are many studies to determinate pre-service teachers and teachers' pedagogical content knowledge, only a few studies (Bukova-Güzel, E., Cantürk-Günhan, B., Kula,S., Özgür,Z. \& Nüket Elçi, A. (2013)) developing the scale related this area was carried out. Therefore, in this study we decided to develop a pedagogical content knowledge scale for pre-service teachers. It is believed that this study provides an important contribution to studies on pedagogical content knowledge.

\section{Method}

In this study, an instrument was developed to determine pre-service teachers' pedagogical content knowledge. This instrument development study was carried out with the participation of 768 pre-service teachers selected from different universities in Turkey.

\subsection{Sample}

The sample of study consists of 768 undergraduates in the Faculty of Education at five different universities in Turkey. Demographic information of the sample is given in table 1.

Table 1. Demographic information of the sample

\begin{tabular}{llcc} 
& & & \\
\cline { 3 - 4 } Gender & Male & Frequencies (f) & Percentage (\%) \\
\hline \multirow{2}{*}{ Grade } & Female & 380 & 49.5 \\
& $3^{\text {rd }}$ year & 588 & 50.5 \\
\hline \multirow{4}{*}{ Department } & 4th year & 239 & 66.7 \\
& $5^{\text {th }}$ year & 17 & 31.1 \\
& Primary Teacher Education & 202 & 2.2 \\
\cline { 2 - 4 } & Science Teacher Education & 247 & 26.3 \\
& Mathematics Teacher Education & 285 & 32.2 \\
& Social science Teacher Education & 34 & 37.1 \\
& & & 4.4 \\
\hline
\end{tabular}

The research sample consists of 380 male and 388 female pre-service teachers. It was determined that 512 of them were 
$3^{\text {rd }}$ year; 239 were $4^{\text {th }}$ year and 17 were $5^{\text {th }}$ year students. In addition, it was seen that 202 of the pre-service teachers were in Primary Teacher Education, 247 were in Science Teacher Education, 285 were in Mathematics Teacher Education and 34 were in Social science Teacher Education department education.

\subsection{Instrumentation}

The pedagogical content knowledge scale is a five point rating scale used to collect data from pre-service teachers. It followed five stages in the development of the scales.

In the first stage, before the scale was developed, we carried out a literature review regarding pedagogical content knowledge by way of document analysis to determine statements of the pedagogical content knowledge scale and how to develop an attitude scale (An, Kulm \& Wu, 2004; Carpenter et al., 1988; Carpenter et al, 1989; Schmidt et al, 2009; Graham et al., 2009; Cochran, DeRuiter \& King, 1993; Magnusson, Krajcik \& Borko, 1999; Şahin 2011; FernandezBalboa \& Stiehl, 1995; Gess-Newsome, 1999; Griffin, Doods \& Rovegno, 1996; Cochran, 1997; Gudmundsdottir, 1990; Clermont, Krajcik \& Borko, 1993; Clermont, Krajcik \& Borko, 1994; Marks, 1990; Mishra \& Koehler, 2006; Metin, 2010). Later, we interviewed 15 pre-service teachers in the $3^{\text {rd }}$ year and $4^{\text {th }}$ year in different universities. During the interview, we asked the teachers open-ended questions about what they thought about content knowledge, their understanding of pedagogical knowledge, what they thought about having knowledge related to pedagogical content knowledge by teachers to determine their perceptions on pedagogical content knowledge. In addition, we asked 20 teachers to write an essay about content knowledge, pedagogical knowledge and pedagogical content knowledge.

In the second stage, benefiting from knowledge gained from the literature, answers from the pre-service teachers and data inferred from the essays written by the teachers, we prepared a draft scale consisting of 55 statements about pedagogical content knowledge. These statements were placed together and seemed to reflect an underlying theme, a process which resulted to three sets each comprising 60 items, preliminary indicators of possible scales. Afterwards, an initial item pool was generated consisting 60 items on a five point rating scale such as "strongly disagree", "disagree", "undecided", "agree" and "strongly agree".

In the third stage, for the purpose of content validation, an initial draft of the attitude scale with 60 items on a five point rating scale was given to a group of six experts in pedagogical content knowledge, educational psychology and educational measurement to obtain their opinions about whether the selected items were valid items for assessing preservice teachers' views related to pedagogical content knowledge. The experts were asked to examine items with regard to their relevance to content coverage, understandability and consistency to one another. In addition, the experts examined the scale and suggested that some items be omitted because they were unsuitable for unclear item and students' level and some be added. According to these suggestions, the researchers omitted 13 items from the scale and added 3 items, made some corrections and prepared a 50 item scale. We carried out a pilot study of this 50 item scale with 15 pre-service teachers. In this stage, we examined all the items in the scale by conducting a group interview with 15 pre-service teachers. In scale development, what the researcher means when using the items in the scale and how the participant interprets these items should be coherent. In addition, the meaning conferred upon these items by other participants should not change (Tourangeau, Rips \& Rasinski, 2000). Furthermore, pre-service teachers controlled the comprehensibility level of the items and whether they were interpreted in the same way by everybody. Then, the researchers arranged all the items on the scale again according to the results so that the participants would interpret them in the same way. As a conclusion, the scale towards pedagogical content knowledge consists of 50 items on a five point rating scale.

In the fourth stage, the final draft of the scale with 50 items was administered to 768 pre-service teachers for calculating the validity (particularly constructing validity) and reliability of the attitude scale. Pre-service teachers' responses were entered into an excel file created for further analyses.

In the last stage, the data collected from pre-service teachers was analysed by means of factor analysis and reliability analysis through the use of SPSS 11.5 and LISREL. Firstly, for the validity of the PCKS, means and standard divisions of upper 27\% (207) and lower 27\% (207) points and t-tests between items' means of upper 27\% and lower 27\% points was calculated. In addition, the data was subjected to factor analysis with the principle component method in order to examine the factor structure behind the attitude scale. The principal components factor analysis was followed by varimax rotation (rotated component matrix). We believed that the variance explained by one factor would be independent of the variance in the other factors. Besides, the factor construction determined through Exploratory Factor Analysis was exposed to confirmatory factor analysis. For confirmatory factor analysis, which helps to determine the relations between items and factors and the relationship among factors, the LISREL 8.51 packet programme was administered. Chi-Square Fit, GFI (Fit Index), AGFI (Adjusted Goodness of Fit Index), RMSEA (Root Mean Square Error 
of Approximation), CFI (Comparative Fit Index), NFI (Normed Fit Index) and RMR (Root Mean Square Residual) fit indexes have been used to evaluate the validity of the model in confirmatory factor analysis. Lastly, reliability analysis was performed for each of the emerged sub-scales and Cronbach alpha correlation coefficients were used. Then, Croanbach alpha correlation coefficients were calculated among these factors.

\section{Findings}

The suitability of the current data gather from the scale for factor analysis was checked through several criteria. First, 768 participants were found to be sufficient for factor analysis according to several resources (Field, 2000; Pallant, 2001). Second, the Kaiser-Meyer-Olkin Measure of Sampling Adequacy (KMO) and Barlett's test was checked. The KaiserMeyer Olkin (KMO) measure of sampling adequacy (KMO) and Barlett's test were calculated to evaluate whether the sample was large enough to apply a satisfactory factor analysis and examine to define appropriateness of factor analysis (Büyüköztürk, 2003). The KMO value varies between 0 and 1. A value close to 1 indicates that patterns of correlations are compact and factor analysis will yield reliable factors (Akbulut, Sahin \& Eristi, 2010; Kline, 1994). KMO values of .60 or above are acceptable (Pallant, 2001; Hair, Anderson, Tatham \& Black, 1998, George \& Mallery, 2001). The KMO value of the initial analysis was .977, which is considered perfect by Hutcheson and Sofroniou (1999). The Bartlett's Test of Sphericity reached a significant value supporting the factorability of the correlation matrix obtained from the items [Approx. Chi-Square: $18571.071(p<0.01)]$. The results Barlett's test of Spherincity statistic was significant. The results of $\mathrm{KMO}$ and Barlett's test appear to support the validity of the factor analysis usage for this study. Thirdly, item analysis of the scale was carried out. Means and standard divisions of upper $27 \%$ and lower $27 \%$ points and $\mathrm{P}$ value and t-tests between items' means of upper $27 \%$ and lower $27 \%$ points in item analysis of the scale for validity of the PCKS items was calculated. Unsuitable items in the scale were determined. After these applications, item analysis, exploratory and confirmatory factor analyses were conducted to date gathers from the scale.

\subsection{Item Analysis of the Scale}

Before the exploratory factor analysis, means and standard divisions of upper $27 \%$ and lower $27 \%$ points and $\mathrm{P}$ value and t-tests between items' means of upper $27 \%$ and lower $27 \%$ points in item analysis of the scale in order to validity of the PCKS items were calculated. Table 2 presents means and standard divisions, $\mathrm{P}$ value and t-tests between items' means of upper $27 \%$ and lower $27 \%$ points in item analysis of the scale

Table 2. Means, standard divisions, P value and t-tests means of upper and lower points

\begin{tabular}{|c|c|c|c|c|c|c|}
\hline \multirow[t]{2}{*}{ Number of Items } & \multicolumn{2}{|c|}{ Upper } & \multicolumn{2}{|c|}{ Lower } & \multirow[b]{2}{*}{$\mathrm{t}$} & \multirow[b]{2}{*}{ p } \\
\hline & $\bar{x}$ & SD & $x$ & SD & & \\
\hline 1 I have knowledge about the context of my lesson & 4.13 & .659 & 2.92 & 1.021 & 14.298 & .000 \\
\hline 2 I know the critical points of my lessons & 4.26 & 602 & 3.12 & 1.069 & 13.477 & .000 \\
\hline 3 I pursue the last improvement regarding teaching lessons & 3.99 & .893 & 2.84 & .908 & 12.963 & .047 \\
\hline 4 I want to participate in a seminar, symposium, workshop related to my scope & 3.75 & 1.011 & 2.51 & .985 & 12.618 & .243 \\
\hline 5 I pursue publication related to my scope & 3.23 & .991 & 2.36 & .918 & 9.247 & .113 \\
\hline 6 I can identify familiar national and international scientists & 3.34 & 1.034 & 2.62 & .946 & 7.337 & .250 \\
\hline 7 I can recognise lacking areas related to my lessons & 4.39 & 650 & 3.41 & 1.038 & 11.521 & .000 \\
\hline 8 I know the basic definitions in my lesson & 4.28 & .656 & 3.15 & .963 & 13.923 & .000 \\
\hline 9 I have knowledge about relation, rule and formula in my lessons & 4.34 & 641 & 3.11 & .878 & 16.177 & .001 \\
\hline 10 I know theory, axiom, theorems etc. in my lesson & 4.06 & .780 & 2.89 & .902 & 14.046 & .001 \\
\hline et the difficulties of students during my lesson & 4.35 & .619 & 3.28 & 1.010 & 12.908 & .000 \\
\hline 12 I can determine that the students may be pressured in my lessons in advance & 4.23 & .669 & 3.26 & .943 & 12.055 & .000 \\
\hline $\begin{array}{l}13 \text { I can prepare an appropriate lesson plan in accordance with the point that students may } \\
\text { be pressured in my lessons }\end{array}$ & 4.41 & 601 & 3.18 & 1.015 & 15.015 & .000 \\
\hline 14 I can notice misconceptions of students in the course of teaching a new topic & 4.17 & .742 & 3.16 & .853 & 12.836 & .006 \\
\hline 15 I can determine misconceptions of students while teaching new topics & 4.20 & .674 & 3.09 & .868 & 14.500 & .001 \\
\hline 16 I can select problems suitable for teaching contexts in my lesson & 4.49 & .590 & 3.31 & .972 & 14.915 & .000 \\
\hline 17 I use teaching methods and techniques suitable for the topic & 4.46 & .563 & 3.23 & .966 & 15.853 & .000 \\
\hline 18 I can contact among topics in the lesson & 4.60 & .510 & 3.35 & 1.018 & 15.749 & .000 \\
\hline 19 I can develop measurements and assessment tools suitable for the topics & 4.39 & .605 & 3.16 & .929 & 15.976 & .000 \\
\hline 20 I can contact between explaining the topic and other topics & 4.45 & .563 & 3.29 & .956 & 15.155 & .000 \\
\hline
\end{tabular}




\begin{tabular}{|c|c|c|c|c|c|c|}
\hline \multirow[t]{2}{*}{ Number of Items } & \multicolumn{2}{|c|}{ Upper } & \multicolumn{2}{|c|}{ Lower } & \multirow[b]{2}{*}{ t } & \multirow[b]{2}{*}{ p } \\
\hline & $\bar{x}$ & SD & $x$ & SD & & \\
\hline 1 I can determine the aim in the course plan & 4.22 & .638 & 3.19 & .923 & 13.204 & .000 \\
\hline 22 I can use different presentation techniques appropriate for the topic & 4.38 & .594 & 3.17 & .943 & 15.597 & .000 \\
\hline 23 I can decide how to connect between old and new topics & 4.43 & .569 & 3.28 & .965 & 14.768 & .000 \\
\hline 4 I consider the pre-knowledge of students regarding cognitive thinking & 4.59 & .558 & 3.35 & 1.022 & 15.222 & .000 \\
\hline $\begin{array}{l}\text { I can present a course to satisfy the demand of students in different grade levels in } \\
\text { teaching topics }\end{array}$ & 4.36 & .615 & 3.02 & .983 & 16.612 & .000 \\
\hline 6 I can connect the topic with daily life & 4.65 & .518 & 3.37 & 1.093 & 15.214 & .000 \\
\hline 7 I try to understand concepts that exemplify with daily life for students in the lesson. & 4.68 & .496 & 3.38 & 1.112 & 15.368 & .000 \\
\hline 28 I know which teaching method and techniques to use for the topic & 4.34 & .594 & 3.05 & .907 & 17.153 & .003 \\
\hline 29 I can select the appropriate teaching method for standards & 4.36 & .573 & 3.14 & .872 & 16.756 & .000 \\
\hline 30 I can take precautions determining the individual differences of students & 4.36 & .589 & 3.11 & .951 & 16.024 & .000 \\
\hline 31 I know how to assess students' performance in the classroom & 4.39 & .588 & 3.25 & .888 & 15.464 & .000 \\
\hline 32 I can organise a suitable learning environment for students & 4.36 & .591 & 3.15 & .905 & 16.073 & .000 \\
\hline 33 I can control negative situations while teaching & 4.38 & .619 & 3.25 & .966 & 14.247 & .000 \\
\hline 34 I know how be connection with students outside of the classroom & 4.63 & .532 & 3.33 & .981 & 16.698 & .000 \\
\hline 35 I can begin different activities which to motivate students for lessons & 4.63 & .503 & 3.30 & .985 & 17.282 & .000 \\
\hline 36 I can effectively use awards, punishments and reinforcers & 4.53 & .629 & 3.35 & 1.003 & 14.262 & .000 \\
\hline 37 I can construct a democratic environment that enables the self-expression of students & 4.59 & .530 & 3.30 & 1.023 & 16.170 & .000 \\
\hline 38 I can use time effectively in the lesson & 4.40 & .607 & 3.08 & .939 & 16.957 & .000 \\
\hline 39 I can determine insufficiency related to vocation and overcome it & 4.54 & .605 & 3.19 & 1.069 & 15.786 & .000 \\
\hline 40 I can use suitable learning and teaching instruments & 4.47 & .556 & 3.24 & .974 & 15.869 & .000 \\
\hline 41 I can effectively use my voice in the lesson & 4.51 & .696 & 3.37 & 1.061 & 12.979 & .000 \\
\hline 42 I can correct as necessary in accordance with students feedback & 4.56 & .545 & 3.31 & 1.067 & 14.909 & .000 \\
\hline 43 I have knowledge about the instructional programme & 4.26 & .644 & 3.05 & .916 & 15.532 & .005 \\
\hline $\begin{array}{l}\text { I I can present systematically in contexts of lessons (from concrete to abstract or from easy } \\
\text { to hard }\end{array}$ & 4.59 & .566 & 3.32 & .973 & 16.234 & .000 \\
\hline 45 I can control my emotions during lessons & 4.29 & .738 & 3.16 & .964 & 13.334 & .006 \\
\hline 46 I have knowledge about learning theories & 4.37 & .609 & 3.11 & .910 & 16.460 & .000 \\
\hline 47 I can consist a useable platform during lesson & 4.41 & .607 & 3.07 & .960 & 16.887 & .000 \\
\hline 48 I can use question-answers activities during lesson & 4.63 & .514 & 3.38 & 1.130 & 14.451 & .000 \\
\hline $\begin{array}{l}49 \text { I can teach concepts using multi representation such as tables, diagrams, graphic and } \\
\text { equation...etc. }\end{array}$ & 4.62 & .534 & 3.28 & .951 & 17.593 & .000 \\
\hline 50 I can prepare lesson plans covering the important points of topics & 4.71 & .468 & 3.34 & 1.090 & 16.521 & .000 \\
\hline
\end{tabular}

$\bar{x}$ : Means, SD: Standard divisions, $\mathrm{P}<0.05$

As seen from table 1, the t-test results showed significant differences between each item's means of upper 27\% and lower 27\% points experts from items 4, 5, and 6. According to this result, 47 items of PCKS are appropriate to measure undergraduates' pedagogical content knowledge.

\subsection{Exploratory Factor Analysis of the Scale}

The aim of exploratory factor analysis is to find the number of separate components that may exist for a group of items (Kline, 1994; Büyüköztürk, 2003). The purpose of exploratory factor analysis was to investigate the factors underlying the PCKS in this study. We began analysis of the data obtained from this study by examining the dimensions obtained from factor analysis of the data. Therefore, exploratory factor analysis was administered to the 50 items. The principle components factor analysis was used on all the data in order to extract the appropriate number of factors. The initial solution revealed that six factors had an eigen value greater than 1 . These factors altogether explained $59.092 \%$ of the variance of results. Overall, three of six factors were represented by just one item per each factor with loading higher than 0.4. Therefore, the one remaining factor was considered uninterpretable. Nine items were deleted because their factor loadings were lower than 0.4 (Kline, 1994; Büyüköztürk, 2003). Nine out of 50 items were deleted and the factor analysis for rotation was run again over the data set with 38 items. The varimax rotation was then used. After using the varimax rotation, the factor loadings for each item were examined. Loadings of less than 0.4 , a commonly-used cut-off, were eliminated. Thus, the factor analysis resulted in independent factors with factor loadings greater than 0.4 . Besides, an alternative approach was used to determine the appropriate number of factors to examine the scree plot produced by the analysis in the study. The scree plot was seen to determine the number of factors (Kline, 1994). 


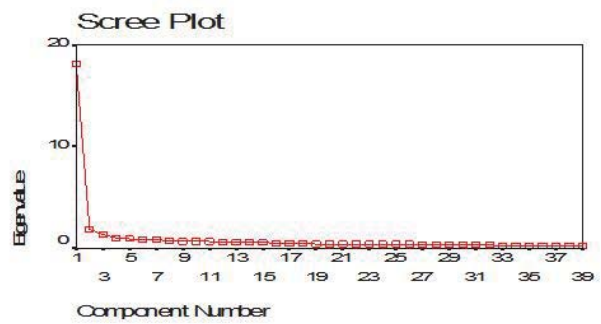

Figure 2 Scree plot of scale

The scree plot shows that three factors were in sharp descent and then started to level off. This was evidence that rotation was necessary for three factors. Two methods of determining the number of factors revealed that the scale regarding pedagogic content knowledge consists of three factors. Table 3 present the eigen values, variances and total variances of the three factors

Table 3 Eigen values, variances and total variances of the five factors

\begin{tabular}{lccc}
\hline Factors & Eigenvalues & Percentages of variances & Percentages of total variances \\
\hline Factor 1 & 17.614 & 46.353 & 46.353 \\
Factor 2 & 1.854 & 4.879 & 51.232 \\
Factor 3 & 1.380 & 3.631 & 54.863 \\
\hline
\end{tabular}

As seen from table 3, there are three factors in the scale. Eigen values of the factors are 1.380, 1.854 and 17.614. Factor 1 explained $46.353 \%$ of total variance, factor 2 explained $4.879 \%$ of total variance and factor 3 explained $3.631 \%$ of total variance. These three factors explained $54.864 \%$ of total variance and were named according to the common characteristics of the items loaded on the same factor. This value is appropriate considering that other works focused on attitudes showed lower explained variance (Spinner and Fraser 2005: 42\%, Kline 1994: 41\%). According to the results of item loading and Eigen values of the factors, it can be said that this attitude scale is appropriate to assess pre-service teachers' pedagogic content knowledge.

After factor numbers of PCKS were determined, distribution of 38 items to three factors was seen. Table 4 presents the factor loadings and factor structures of the items.

Table 4 Factor Structures and Loadings of the 38 Items in PCKS

\begin{tabular}{|c|c|c|c|c|}
\hline \multicolumn{2}{|c|}{ 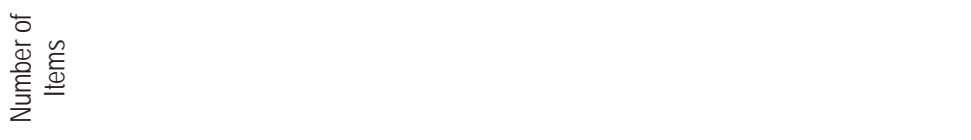 } & \multirow{2}{*}{ 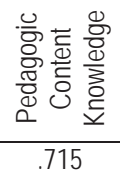 } & \multirow[t]{2}{*}{ 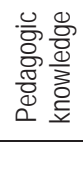 } & 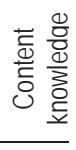 \\
\hline 42 & I can correct as necessary in accordance with students' feedback & & & \\
\hline 48 & I can use question-answers activities during lessons & .707 & & \\
\hline 32 & I can organize a suitable learning environment for students & 681 & & \\
\hline 35 & I can begin different activities to motivate students for lessons & 678 & & \\
\hline 44 & I can present systematically in contexts of lessons (from concrete to abstract-.. etc.- ) & 677 & & \\
\hline 47 & I can consist a useable platform during lessons & 677 & & \\
\hline 34 & I know how to connect with students outside of the classroom & 676 & & \\
\hline 50 & I prepare lesson plans considering the important points of topics & 674 & & \\
\hline 40 & I can use suitable learning and teaching instruments & 670 & & \\
\hline 37 & I can construct a democratic environment that provides self-expression of students & .667 & & \\
\hline 49 & I can teach concepts using multi-representation as tables, diagrams, graphic equation & .664 & & \\
\hline 33 & I can control negative situations while teaching lessons & .653 & & \\
\hline 36 & I can effectively use award, punishment and reinforcers & .646 & & \\
\hline 30 & I can take precautions determining the individual differences of students & .643 & & \\
\hline 27 & I try to understand concepts that exemplify with daily life for students in the lesson. & 638 & & \\
\hline 38 & I can use time effectively in the lesson & .629 & & \\
\hline 31 & I know how to assess students' performance in the classroom & .625 & & \\
\hline
\end{tabular}




\begin{tabular}{|c|c|c|c|c|}
\hline 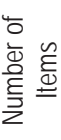 & & 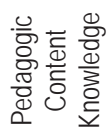 & 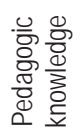 & 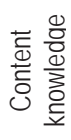 \\
\hline 41 & I can effectively use my voice in the lesson & .617 & & \\
\hline 39 & I can determine insufficiency related to vocation and overcome it & .613 & & \\
\hline 46 & I have knowledge about learning theories & .588 & & \\
\hline 29 & I can select appropriate teaching methods for standards & .584 & & \\
\hline 43 & I have knowledge about the instructional programme & .574 & & \\
\hline 45 & I can control my emotions during lessons & .544 & & \\
\hline 28 & I know which teaching methods and techniques to use for the topic & .502 & & \\
\hline 14 & I can notice misconception of students in the course of teaching a new topic & & .719 & \\
\hline 15 & I can determine misconceptions of students during teaching new topics & & .713 & \\
\hline 13 & $\begin{array}{l}\text { I can prepare appropriate lesson plans in accordance with the point that the students may be } \\
\text { pressured in my lessons }\end{array}$ & & .657 & \\
\hline 11 & I can meet the difficulties of students during my lesson & & .638 & \\
\hline 12 & I can determine the point that the students may be pressured in my lessons in advance & & .626 & \\
\hline 16 & I can select problems suitable for teaching contexts in my lesson & & .595 & \\
\hline 18 & I can contact among topics in the lesson & & .480 & \\
\hline 9 & I have knowledge about relation, rule and formula in my lessons & & & .712 \\
\hline 1 & I have knowledge about the context of my lesson & & & .686 \\
\hline 2 & I know the critical points of my lessons & & & .684 \\
\hline 10 & I know theory, axiom, theorems etc in my lesson & & & 648 \\
\hline 8 & I know the basic definitions in my lesson & & & .618 \\
\hline 3 & I pursue the last improvement regarding teaching lessons & & & .601 \\
\hline 7 & I can recognize lacking areas related to my lessons & & & .409 \\
\hline
\end{tabular}

As seen in table 4, factor loading of items in the scale changes between 0.409 and 0.719 . Kline (1994) said that the value of factors load between 0.30 and 0.60 is medium and between 0.6 and 1.0 is high quality. This situation indicated that 38 of the item are qualified enough in the scale.

As seen in the distribution of 38 items to three factors, factor 1 includes twenty four items: $27,28,29,30,31,32$, $33,34,35,36,37,38,39,40,41,42,43,44,45,46,47,48,49$ and 50. These items explicitly measure pre-service teachers' pedagogical content knowledge in lessons. This factor was therefore named "pedagogical content knowledge (PCK)". Factor 2 includes seven items: 11, 12, 13, 14, 15, 16 and 18. These items explicitly measure pre-service teachers' pedagogical knowledge in lessons. This factor was named "pedagogical knowledge (PK)". Factor 3 includes seven items: 1, 2, 3, 7, 8, 9 and 10. These items explicitly measures pre-service teachers' content knowledge in lesson. This factor was therefore named "content knowledge (CK)".

\subsection{Confirmatory Factor Analysis of Scale (with 662 pre-service teachers)}

The aim of confirmatory factor analysis is examining how much a construct or explanation previously established can be confirmed through the gathered data (Büyüköztürk et al. 2004). For this purpose, the three-factor construct obtained through exploratory factor analysis has been analysed and the fitness of the construct has been analysed according to the results of fitness statistics and the modification index.

The fit of the model was evaluated with various measures (Sörbom \& Jöreskog, 1982). Kelloway (1998) has suggested that the use of the chi-square test is reasonable when the study involves a large sample. However, as the chisquare is very sensitive to sample size, the degree of freedom can be used as an adjusting standard by which to judge whether the chi-square is large or small (Jöreskog, \& Sörbom, 1989). Other types of goodness-of-fit measures include Root Mean Squared Error of Approximation (RMSEA), Root Mean Square Residual (RMR), Standardised RMR (SRMR), Normed Fit Index (NFI), Non-Normed Fit Index (NNFI), the Comparative Fit Index (CFI), Goodness of Fit Index (GFI), and the Adjusted Goodness of Fit Index (AGFI). RMSEA and RMR values close to zero show a near perfect fit. The NFI, $\mathrm{NNFI}, \mathrm{CFI}, \mathrm{GFI}, \mathrm{AGFI}$ are always between zero and one, with any value above 0.9 indicating a good fit and one suggesting a perfect fit.

Results of goodness-of-fit measurements were: $x 2=2367.46(d f=662, p<0.000),(x 2 / d f)=3.576$, Goodness of Fit Index $(\mathrm{GFI})=0.86$, Normed Fit Index $(\mathrm{NFI})=0.88$, Non-Normed Fit Index $(\mathrm{NNFI})=0.91$, Root Mean Square Residual $($ RMSEA $)=0.057$, Adjusted Goodness of Fit Index $(A G F I)=0.85$, Comparative Fit Index $(C F I)=0.91$, Root Mean Square 
Residual $(\mathrm{RMR})=0.027$ and Standardized RMR $(\mathrm{SRMR})=0.038$. All of the t-values of items showed statistical significance at the 0.05 level. The ratio of the model was 3.576 , indicating a fairly good fit. The model had a RMSEA of 0.0057 , SRMR of 0.038 , and $\mathrm{NFI}, \mathrm{NNFI}$, and CFI values over 0.88 , showing that the model had a highly satisfactory fit.

According to the results of the confirmatory factor analysis, it is seen that the model is reasonably good. The results can be interpreted thus: The GFI value seems to be 0.86 in the analyses. When this value is close to 1 , the fitness degree of the model becomes closer to excellent. According to obtained value, the model has achieved an almost excellent harmony to the data. Similar to GFI are the values of AGFI, CFI and NFI, while other assessment measurements close to 0.90 indicate excellent fitness (Hair et al. 1998). It can be said that the three-factor model is in consistence with this. When all these results are analysed, it has been determined that the scale consisting of 38 items is suitable to the measurements in the confirmatory factor analysis. The path diagram, which shows the standardised coefficients between item latent variable and latent variables, are shown in figure 3.

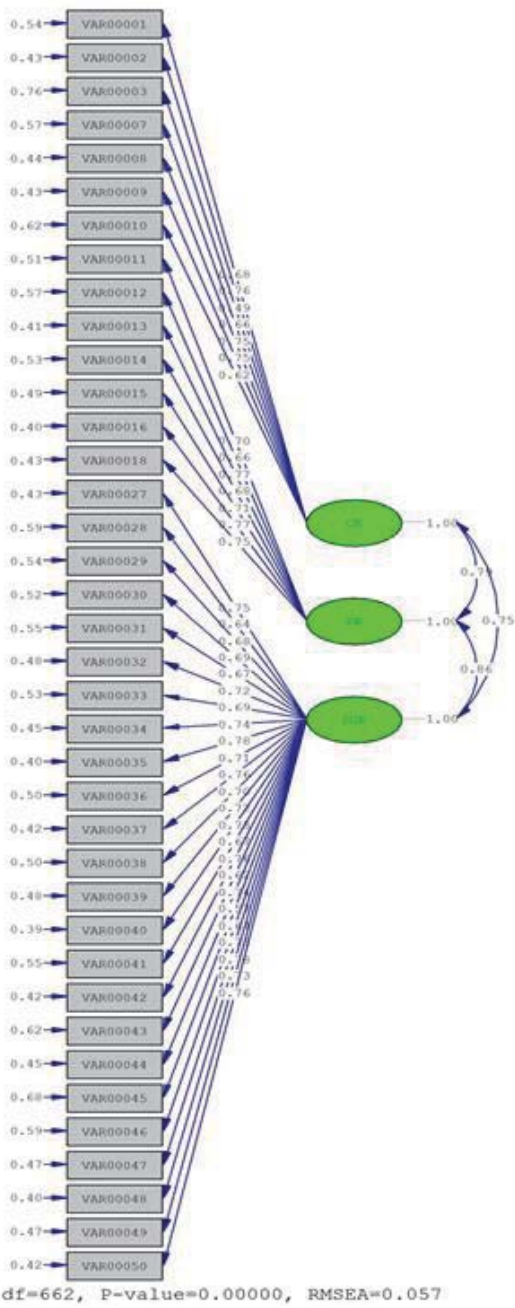

Figure 3. Path diagram of the scale

\subsection{Reliability of the scale}

Reliability analysis was administered for each factor and Cronbach alpha correlation coefficients were used. Then, Croanbach alpha correlation coefficients were calculated among these factors. Table 5 summarises factor names, 
number of the items and reliability of each factor.

Table 5 Factor names, number of the items and Cronbach alpha value of each factor

\begin{tabular}{lcc}
\hline Factors name & Number of items & $\begin{array}{c}\text { Coefficient items } \\
\text { Cronbach Alpha }\end{array}$ \\
\hline Content knowledge (CK) & 7 & 0.849 \\
Pedagogical knowledge (PK) & 7 & 0.885 \\
Pedagogical content knowledge (PCK) & 24 & 0.961 \\
Total Scale & 38 & 0.967 \\
\hline
\end{tabular}

As seen in table 5, it was determined that Cronbach alpha value of CK is 0.849 , PK is 0.885 and PCK is 0.961 . Also, it was found that the Cronbach alpha value of total scale is 0.967 . According to these results, it can be said that the scale regarding pedagogical content knowledge valuable and reliable.

\section{Discussions and Conclusions}

Last two decade many studies have been performed related to pedagogical content knowledge (Fernandez-Balboa and Stiehl, 1995; Griffin, Dodds, and Rovegno, 1996; Magnusson, Krajcik and Borko, 1999; Capraro, Margaret, Parker, Kulm and Raulerson, 2005; Baker and Chick, 2006, Bukova-Güzel, E., Cantürk-Günhan, B., Kula,S., Özgür,Z. \& Nüket Elçi, A. 2013). While it is possible to obtain an opinion about this subject with appropriate actions, it is very difficult to determine the level of teachers or pre-service teachers' pedagogical content knowledge. So, it is important that the scale determine the level of pre-service teachers' pedagogical content knowledge is developed. For this reason, the aim of this study is to develop a scale in order to determinate pre-service teachers' pedagogical content knowledge.

In this study, the pedagogical content knowledge scale was developed through the use of five stage model proposed. Subsequent to a review of literature and carried out interview with pre-service teachers, composed item pool, validated the item pool across the experts and then initial draft of the instrument was constructed. Later, this initial draft was reviewed by the experts, PCKS was administered to 768 pre-service teachers in different University to the factorial structure of the scale, provide validity and further reliability evidences. Lastly validity and reliability of the attitude scale were calculated.

Factor analysis with principle component methods and item analysis result revealed three factors behind PCKS which explain $54.864 \%$ of the total variance together. This value is appropriate considering that other works focused on attitudes showed lower explained variance (Spinner and Fraser 2005: 42\%, Kline 1994: 41\%). According to results of item loading of the factors, it is said that the scale is appropriated to assess pre-service teachers' pedagogic content knowledge. These factors determined by exploratory factor analysis are such as content knowledge (7 items), pedagogical knowledge (7 items) and pedagogical content knowledge (24 items).

First factor of scale entitle content knowledge is described as one of the major components of PCK. Shulman (1987) and Grossman (1990) were expressed that content knowledge is the foundation knowledge or component of PCK. Content knowledge includes knowledge of the subject and its organizing structures (Grossman, Wilson, \& Shulman, 1989; Shulman, 1986b, 1987; Wilson, Shulman, \& Richert, 1987). Shulman (1986) defined; this knowledge would include knowledge of concepts, theories, ideas, organizational frameworks, knowledge of evidence and proof, as well as established practices and approaches toward developing such knowledge. Content knowledge is a technical knowledge key to the establishment of teaching as a profession. Namely, an effective teaching will occur when the subject is taught by teachers with the appropriate specialization. Besides, while teacher content knowledge is crucially important to the improvement of teaching and learning, attention to its development and study has been irregular. In other words, it is not possible to perform teaching activities without having good content knowledge. Teachers need to have all the information about what they teach the students can reach the true information. Pre-service teacher also need to be aware of their case about the content knowledge and to develop this direction permanently. It is thought that content knowledge factor is important to developing this scale because of these features of content knowledge.

Second of scale entitle on pedagogic knowledge is described the other components of PCK. Teachers having content knowledge don't mean that they can teach very well. Teachers and pre-service teacher need to have mastership knowledge including teaching and learning methods. It means they need to be endowed with good pedagogy knowledge. Again as in content knowledge, pre-service teachers also need to be aware of their case about the pedagogy knowledge and they should provide what's necessary. Pedagogical Knowledge is deep knowledge about the processes and 
practices or methods of teaching and learning and how it encompasses overall educational purposes, values and aims (Koehler \& Mishra, 2008). Besides pedagogic knowledge that is involved in all issues of student learning, classroom management, lesson plan development and implementation, and student evaluation. It includes knowledge about techniques or methods to be used in the classroom; the nature of the target audience; and strategies for evaluating student understanding (Koehler \&Mishra, 2009). Teachers with deep pedagogical knowledge understand how students construct knowledge and acquire skills; develop habits of mind and positive dispositions towards learning. As such, pedagogical knowledge requires an understanding of cognitive, social and developmental theories of learning and how they apply to students in their classroom (Mishra \& Koehler, 2006). Because of these properties of pedagogic knowledge, this factor is necessary in the scale in order to measure whether pre-service have these qualifications or not.

Third of scale entitle on pedagogical content knowledge is defined as an important constituent of PCK. PCK involves the essential occupations of teaching, learning, curriculum, assessment and reporting, such as the case that promote learning and the links among curriculum, assessment, and pedagogy (Koehler \& Mishra, 2009). Besides PCK comprises to an awareness of common misconceptions and ways of looking at them, the importance of forging connections among different content-based ideas, students' prior knowledge, alternative teaching strategies, and the flexibility that comes from exploring alternative ways of looking at the same idea or problem are all essential for effective teaching. So, teachers and pre-service teacher need pedagogical content knowledge including the items of pedagogy and content knowledge. PCK, when analyzed deeply, can deal out as an important premise in the process which teachers turn into an experienced practitioner from an apprentice (Clermont, Krajcik \& Borko, 1994). Therefore it is really important for teachers to be aware of the level of their pedagogical content knowledge. Thus they can detect their missing directions and make efforts to develop themselves about this topic. Because of these properties of pedagogic knowledge, this factor is necessary in the scale in order to measure whether pre-service have these qualifications or not.

After factor analysis and naming of factors, confirmatory factor analysis has been performed with 662 pre-service teachers different from the sample using explanatory factor analysis In order to confirm the construct obtained through exploratory factor analysis, According to this analysis results, the calculated values are thus: $\chi 2=2367.46$ ( $d f=662$, $\mathrm{p}<0.000),(X 2 / \mathrm{df})=3.576, \mathrm{CFI}=0.91, \mathrm{GFI}=0.86, \mathrm{NFI}=0.88, \mathrm{NNFI}=0.91, \mathrm{RMSEA}=0.057, \mathrm{AGFI}=0.85, \mathrm{CFI}=0.91, \mathrm{RMR}=$ 0.027 and SRMR $=0.038$. It has been understood that all factor loads in the model are meaningful (pl0.05). It can be said that the three-factor model is compatible with the data in terms of the defined criteria. In addition to alpha correlation, coefficients of five factors were calculated using Croanbach alpha reliability of the factors and ranged from 0.849 to 0.961, indicating acceptable reliability range (Kline, 1994; Fraser, 1989). The overall scale reliability was calculated as 0.967. According to the results, it must be emphasized that the PCKS, which allows researchers to study pre-service teachers' pedagogical content knowledge level, was developed.

\section{References}

Akbulut, Y., Sahin, Y.L., and Eristi, B. (2010) Development of a scale to investigate cybervictimization among online social utility members. Contemporary Educational Technology, 1 (1), 46-59.

Akkoc, H., Yesildere, S., \& Ozmantar, F. (2007). Prospective Mathematics Teachers' Pedagogical Content Knowledge of Definite Integral: The Problem of Limit Process. British Society of Research in Mathematics Learning (BSRLM), University of Northampton, ENGLAND

Akkoc, H., Ozmantar, F. ve Bingolbali, E. (2008). "Developing a program for pre-service mathematics teachers which aims to develop technological pedagogical content knowledge", Scientific and Technological Research Council of Turkey (TUBITAK) project number 107K531

An, S., Kulm, G. \& Wu, Z. (2004) The pedagogical content knowledge of middle school, mathematics teacher in China and the U.S. Journal of Mathematics Teacher Education, 7, 145-172.

Baker, M., \& Chick, H. L. (2006). Pedagogical content knowledge for teaching primary mathematics: A case study of two teachers. In 29th Conference of the Mathematics Education Research Group of Australasia (Vol. 1, pp. 60-67).

Boz, N. (2004). Determinate student' mistakes and investigate reasons of these mistakes XIII. National Education Sciences Conference, 06-09 July, Inönü University, Malatya

Bukova-Güzel, E., Cantürk-Günhan, B., Kula,S., Özgür,Z. \& Nüket Elçi, A. (2013). Scale development for pre-service mathematics teachers' perceptions related to their pedagogical content knowledge. South African Journal of Education 33(2).

Büyüköztürk, Ş. (2003) Sosyal bilimler için veri analizi el kitabı: İstatistik, araştırma deseni, SPSS uygulamları ve yorum (Geliştirilmiş 3.Baskı). Ankara: Pegema Yayınları.

Büyüköztürk, Ş., Akgün, O., Kahveci, Ö. \& Demirel, F. (2004). The validity and reliability study of the Turkish version of the motivated strategies for learning questionnaire. Educational Sciences: Theory \& Practice, 4(2), 207-239.

Canbazoğlu, S. (2008). Assessment Of Pre- Servıce Elementary Scıence Teachers' Pedagogıcal Content Knowledge Regardıng The Structure Of Matter. Unpublished Master Thesis, Gazi University, Educations Science Institute, Department of Elementary 
Science Education, Ankara.

Carlsen, W. S., (1987) 'Why Do You Ask? The Effects of Science Teacher Subject-Matter Knowledge on

Teacher Questioning and Classroom Discourse', Eric document: ED293181.

Carpenter, T. P., Fennema, E., Peterson, P., \& Carey, D. A. (1988). Teachers' pedagogical content knowledge of students' problem solving in elementary arithmetic. Journal for Research in Mathematics Education, 19(5), 385-401.

Carpenter, T., Fennema, E., Peterson, P., Chiang, C., Loef, M., (1989). Using knowledge of children's mathematics thinking in classroom teaching: An experimental study. American Educational Journal, 26, 499-531.

Chick, H. L. (2009). Choice and use of examples as a window on mathematical knowledge for teaching. For the Learning of Mathematics, 29 (3), 26-30

Clermont, C. P., Krajcik, J. S. \& Borko, H. (1993). The influence of an intensive inservice workshop on pedagogical content knowledge growth among novice chemical demonstrators. Journal of Research in Science Teaching, 30(1), 21-43.

Clermont, C. P., Krajcik, J. S. \& Borko, H. (1994). Comparative study of the pedagogical content knowledge of experienced and novice chemical demonstrators. Journal of Research in Science Teaching, 31(4), 419-441.

Cochran, K. F., DeRuiter, J. A., King, R. A. (1993). Pedagogical Content Knowing: An Integrative Model for Teacher Preparation. Journal of Teacher Education, 44, 263-272.

Cochran, K. F. (1997). Pedagogical content knowledge: Teachers' integration of subject matter, pedagogy, students, and learning environments [online]. Research matters-to the science teacher, No. 9702, Jan. 14.

Dershimer, G. M., Kent, T. (2003). The Complex Nature and Sources of Teacher's Pedagogical Knowledge. In J. Gess-Newsome and N.G. Lederman (Eds.), Examining Pedagogical Content Knowledge. (21-50). Dordrecht, The Netherlands: Kluwer Academic Publishers.

Fernandez-Balboa, J.-M., Stiehl, J. (1995). The Generic Nature of Pedagogical Content Knowledge Among College Professors. Teaching and Teacher Education, 11, 293-306.

Field, A. (2000). Discovering statistics using SPSS for windows, London: Sage Publications.

George D. and Mallery, P (2001) SPSS for Windows: Step by Step. Allyn \& Bacon, USA.

Gess-Newsome, J. (1999). Pedagogical Content Knowledge: An Introduction and Orientation, In J. Gess-Newsome and N.G. Lederman (Eds.), Examining Pedagogical Content Knowledge. (51-93). Dordrecht, The Netherlands: Kluwer Academic Publishers.

Gödek, Y., (2002). The development of science student teachers' knowledge base in England. Unpublished doctoral dissertation, University of Nottingham, England.

Graham, C. R., Burgoyne, N., Cantrell, P., Smith, L., St. Clair, L., \& Harris, R. (2009). TPACK Development in Science Teaching: Measuring the TPACK Confidence of Inservice Science Teachers, TechTrends, Special Issue on TPACK, 53(5), 70-79.

Griffin, L., Dodds, P. \& Rovegno, I. (1996). Pedagogical content knowledge for teachers: Integrative everything you know to help students learn. Journal of Physical Education, Recreation, and Dance, 67(9), 58-61

Grossman, P. L. (1990). The Making of a Teacher: Teacher Knowledge and Teacher Education. New York: Teachers College Press.

Gudmundsdottir, S. (1990). Values in pedagogical content knowledge. Journal of Teacher Education, 41(3), 44-52

Hair, J.F., Anderson, R.E., Tatham, R.L., \& Black, W.C., (1998) Multivariate data analysis (5th edition), New Jersey, Prentice Hall.

Hutcheson, G., and Sofroniou, N. (1999) The multivariate social scientist. London: Sage.

Jöreskog, K. G., \& Sörbom, D. (1989). LISREL 8: Users references guide (2nd Ed.). Lincolnwood, IL: SSI.

Kelloway, E. K. (1998). Using LISREL for structural equation modeling: A researcher guide. Newbury Park, CA: Sage.

Koehler, M. J., \& Mishra, P. (2009). What is technological pedagogical content knowledge? Contemporary Issues in Technology and Teacher Education, 9(1), 60-70.

Kline, P. (1994) An Easy Guide to Factor Analysis, London: Routledge

Magnusson, S., Krajcik, J., Borko, H. (1999). Nature, Sources and Development of Pedagogical Content Knowledge for Science Teaching. In J. Gess- Newsome and N.G. Lederman (Eds.), Examining Pedagogical Content Knowledge. (95-132). Dordrecht, The Netherlands: Kluwer Academic Publishers.

Marks, R. (1990). Pedagogical Content Knowledge: from a Mathematical Case to A Modified Conception. Journal of Teacher Education, $41(3), 3-11$.

MNE, (2008), Teachers proficiency: general and private content adequacies of teaching profession, Ankara, Management of Government Books.

Metin, M. (2010) A Study on Developing a General Attitude Scale about Environmental Issue for Students in Different Grade Level, AsiaPacific Forum on Science Learning and Teaching, 11, (2), 3.

Mishra, P., \& Koehler, M. J. (2006). Technological pedagogical content knowledge: A framework for integrating technology in teachers' knowledge. Teachers College Record, 108(6), 1017-1054.

National Research Council. (2000) How people learn: Brain, mind, experience, and school. Washington, DC: National Academy Press.

Pallant, J. (2001). SPSS survival manual, Maidenhead, PA: Open University Press.

Pfundt, H., \& Duit, R. (2000). Bibliography: Student's alternative frameworks and science education (5th ed.). Kiel, Germany: University of Kiel.

Rovegno, I. C. (1992). Learning to teach in a field-based methods course: the development of pedagogical content knowledge. Teaching and Teacher Education, 8(1), 69-82.

Sahin, İ. (2011). Development of Survey of Technological Pedagogical and Content Knowledge (TPACK). The Turkish Online Journal of Educational Technology (TOJET), 10 (1), 97-105 
Schmidt, D., Baran, E., Thompson, A., Koehler, M.J., Shin, T, \& Mishra, P. (2009, April). Technological Pedagogical Content Knowledge (TPACK): The Development and Validation of an Assessment Instrument for Preservice Teachers. Paper presented at the 2009 Annual Meeting of the American Educational Research Association. April 13-17, San Diego, California.

Shulman, L. S. (1986a). Paradigms and research programs in study of teaching: A contemporary perspective. In Wittrock, M.C. (ed). Handbook of research on teaching. pp.3-36. Macmillan, New York

Shulman, L. S. (1986b). Those who understand: Knowledge growth in teaching. Educational Researcher, 15, 4-14.

Shulman, L.S. (1987). Knowledge and teaching: foundations of the new reform. Harvard Educational Review, 57(1), 1-22.

Smith, D. C, \& Neale, D. C. (1989). The construction of subject matter knowledge in primary science teaching. Teaching and Teacher Education, 5, 1-20.

Sörbom, D., \& Jöreskog, K. G. (1982). The use of structural equation models in evaluation research. In C. Fornell (Ed.), Measurement and Evaluation: Vol. 2. A second generation of multivariate analysis (pp.381-418). New York: Praeger.

Spinner H, and Fraser B. J, (2005) Evaluation of an innovative mathematics program in terms of classroom environment, student attitudes, and conceptual development, International Journal of Science and Mathematics Education, 3, 267-293

Tabachnick, B., and Fidell, L. (2007) Using multivariate statistics, Boston: Allyn \& Bacon.

Thoren, I., Kellner, E., Gullberg, A., Attorps, I. Developing Transformative Pedagogical Content Knowledge in Science and Mathematics Teacher Education. www.hig.se/pdf/n-inst/Slutrapport0501F3.pdf> (14.05.08).

Timur, B, \& Taşar, M,F,(2011), The Adaptation of the Technological Pedagogical Content Knowledge Confidence Survey into Turkish, Gaziantep University, Social Sciences Education, 10(2), 839-856.

Tourangeau, R., Rips, J., \& Rasinski, K. (2000). The psychology of survey response. Cambridge: Cambridge University Press.

Turnuklu, B. E. (2005). Matematik Öğretmen Adaylarının Pedagojik Alan Bilgileri ile Matematiksel Alan Bilgileri Arasındaki Illişki. Eurasian Journal Of Educational Research, 21, pp.234 - 247.

Usak, M, (2005), Prospective Elementary Science Teachers' Pedagogical Content Knowledge about Flowering Plants, Unpublishing Doctoral Thesis, Gazi University, Educations Science Institute, Department of Elementary Science Education, Ankara.

Yesildere, S. (2008). Pre-Service Elementary Mathematics Teachers' Pedagogical Content Knowledge about Number Patterns, VIII, International Sciences and Mathematics Education Conference, Bolu: Abant Izzet Baysal University.

Wilson, S.M, Winwberg, S.S. (1989) Peering at history through different lenses: The role of disciplinary perspectives in teaching history. Teaching College Record, 89, 525-39

Zembylas, M. (2007). Emotional ecology: The intersection of emotional knowledge and pedagogical content knowledge in teaching. Teacher and Teacher Education, 23:355-367 